International Journal of Life Sciences
Available online at http://sciencescholar.us/journal/index.php/ijls
Vol. 2 No. 3, December 2018, pages: 111 120
e-ISSN: 2550-6986, p-ISSN: 2550-6994
https://doi.org/10.29332/ijls.v2n3.220

\title{
Susceptibility to Flooding in Abdon Calderon of Canton Portoviejo Parish
}

\author{
Arturo Andres Hernandez Escobar a, Diego Raul Vera Solorzano b ${ }^{\text {}}$, María Rodriguez Gamez ${ }^{\mathrm{c}}$
}

Article history: Received 10 April 2018, Accepted: 30 August 2018, Published: 14 November 2018

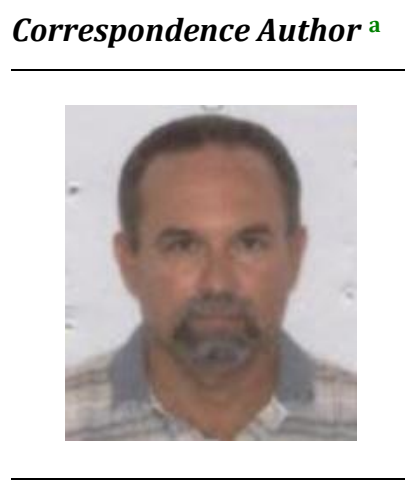

Keywords

Flood;

Geographic information systems;

Precipitation;

Susceptibility;

Winter season;

\begin{abstract}
This research was developed in the field of risk management against floods with the application of Geographic Information Systems (GIS) to assess the susceptibility to flooding in the central part of the Abdón Calderón parish of the Portoviejo canton where there are geographical and climatic characteristics that create favorable conditions for the occurrence of this phenomenon (slopes, edaphic composition with significant presence of clay and existence of patterns of intense rainfall in the winter season. Work was proposed to determine the susceptibility to flooding to which the research area is subject through the analysis of cartographic data and the thematic maps of slope and soil with a weighting methodology of the importance of the mentioned variables according to the qualitative evaluation. Iva carried out preliminarily through observation visits and taking of reference data in situ. The result was the obtaining of a susceptibility map where the high, medium and low susceptibility level can be observed in the downtown part of the Abdón Calderón parish.
\end{abstract}

e-ISSN: 2550-6986, p-ISSN: 2550-6994C Copyright 2018. The Author. SS Journals Published by Universidad Técnica de Manabí. This is an open-access article under the CC BY-SA 4.0 license (https://creativecommons.org/licenses/by-sa/4.0/) All rights reserved.

\section{Contents}

Abstract

1. Introduction.

2. Materials and Methods.

3. Results and Discussions

4. Conclusion

References..

a Ph.D. in Pedagogical Sciences Universidad Estatal del sur de Manabí, (UNESUM), Jipijapa, Manabí, Ecuador

b Environmental engineer, Universidad Estatal del sur de Manabí, (UNESUM), Jipijapa, Manabí, Ecuador

c Ph.D. Engineering career in electricity, Universidad Técnica de Manabí, Portoviejo, Ecuador 


\section{Introduction}

Floods are cataloged as the most frequent and damaging catastrophe of natural origin at a global level. However, not all of them have the same repercussions, it depends on the intensity and duration of rainfall, the geology of the area and the strategies to reduce the impact caused. A flood (from the Latin inundatio-onis) according to the dictionary of the Royal Spanish Academy, is the action and effect of flooding, that is, covering the land and sometimes the populations. The Basic Guideline for Civil Protection Planning for Flood Hazards (MJI 1995) defines flooding as the temporary submersion of normally dry land as a result of the unusual and more or less sudden contribution of a quantity of water superior to that which is usual in a certain area. For its part, the new European Flood Directive (2007/60 / EC) defines flooding as the "temporary flooding of land that is not normally covered by water" (A. Diez-Herero, 2008).

According to (OMM / UNESCO, 1974), cited by Espinosa et al., (2014), flood is understood as an event that, due to precipitation, waves, storm surges, or failure of some hydraulic structure causes an increase in the level of the free surface of the water of the rivers or the sea itself, generating invasion or penetration of water in places where there is usually none and, generally, damage to the population, agriculture, livestock, and infrastructure. According to the Fourth Assessment Report of the year 2007 of the Intergovernmental Panel on Climate Change (IPCC), it mentions in its information that the floods have increased since the last decade and that they will continue that trend as a consequence of climate change and population increase in areas susceptible to this phenomenon (IPCC, 2017).

According to Jha et al., (2012), floods are the most recurrent disaster-causing phenomenon in the world, especially in the last 20 years, where material and human losses also increased. In Latin America, floods have had a significant impact in recent decades due to the poor planning of human settlements at different levels of prevention and mitigation, which causes many human losses, considerable material damage, and incalculable environmental damage. No doubt the effect caused by floods triggered by severe delays in the development of society (resource degradation that supports the main productive and economic activities, destruction of infrastructure, property and the very integrity of people. As it corresponds to the Ecuadorian territory the floods have also been felt and with great intensity especially in the last two decades of the twentieth century, which presented the largest and most damaging floods in the history of Ecuador, being the provinces of Guayas, Manabí, Los Ríos, Esmeraldas and El Oro the most affected (Organization Panamericana Health, 2008).

According to the National Secretariat for Risk Management, one of the potential threats of Ecuador are flooding (Secretariat of Risk Management, 2014), especially in the Litoral region where there are geomorphological and hydrological conditions that they contribute to the phenomenon. In addition, those areas identified as susceptible are where most of the population of this part of the country is concentrated. At the provincial level, the situation is similar since Manabi is one of the provinces most affected by this phenomenon whose relief and soil composition act as responsible.

In this context the Abdón Calderón parish is not far from this situation, since it has specific geographic physical characteristics and therefore has a high probability of frequent flooding because it is located in the flattest part of the sub-basin of the River Chico (tributary of the Portoviejo River) in an area contiguous to its bed so that over time have formed a number of aspects that cause susceptibility in its territory. It should be noted that at present the area does not have studies on the subject addressed and that is highly necessary for the management and safe and orderly occupation of the territory.

For this reason, the present project was designed to make a susceptibility map by using the GIS and the analysis of variables to determine the areas with the highest probability of flooding in the area of influence of the study pertaining to the downtown part of the Abdón Calderón parish, starting from a methodology of study of application type for the effect, since it allows us to develop those already existing for the subject researched and of the study area. Those models of evaluation of susceptibility start from a general analysis of the geo-environmental factors and a practical design of description and representation of their values associated with the research object. 


\section{Materials and Methods}

The growing interest to study in depth the present risks leads to looking for new alternatives to be able to analyze them in order to estimate and represent them within the territory as a mechanism for the prevention and mitigation of the impacts that they can cause to society.

Currently, there are many effective methods to assess the susceptibility to floods according to the assessment and importance assigned to each of the variables involved in the phenomenon.

The methodology applied in the present investigation consisted of considering the three most influential variables or geo-environmental factors (soils, slope, and precipitation). From that, a general weighting was established to give it a level of susceptibility according to the parameterization of the variables (Sarkar, 2004).

\section{Parameterization of variables}

All variables can be assigned parameters of susceptibility terms and values as shown in the following table 1.

Table 1

Parameterization of the variables

\begin{tabular}{cc}
\hline Category of susceptibility & Degree of susceptibility \\
\hline 1 & Low \\
2 & Average \\
3 & High \\
\hline
\end{tabular}

Table 2 shows the classification of flood susceptibility, considering three variables (slopes, lithology, and precipitation.

Table 2

Classification of flood susceptibility

\begin{tabular}{|c|c|c|c|c|c|}
\hline \multirow{4}{*}{ CLASSIFICATION 1} & \multirow{3}{*}{ PENDING } & \multirow{3}{*}{$\begin{array}{c}\text { Range } \% \\
>5 \% \\
2 \%\end{array}$} & \multirow{3}{*}{$\begin{array}{c}\text { Variable } \\
\text { Slightly flat }\end{array}$} & \multirow{3}{*}{$\begin{array}{c}\text { Criteria } \\
\text { Low }\end{array}$} & \multirow[t]{3}{*}{ Color assigned } \\
\hline & & & & & \\
\hline & & & & & \\
\hline & \multirow{5}{*}{ PRECIPITATION } & & Composition & Criteria & Color assigned \\
\hline \multirow{12}{*}{ CLASSIFICATION 2} & & & $\begin{array}{l}\text { Conglomerates } \\
\text { gravels and } \\
\text { sands. }\end{array}$ & Low & \multirow{3}{*}{ Color assigned } \\
\hline & & Measurement & Variable & Criterion & \\
\hline & & $300-500 \mathrm{~mm} / \mathrm{a}$ & $\begin{array}{c}\text { Low } \\
\text { precipitation }\end{array}$ & Very low & \\
\hline & & Ranges\% & Variables & Criteria & Color assigned \\
\hline & \multirow[t]{2}{*}{ PENDING } & \multirow[t]{3}{*}{$2 \%-0 \%$} & Moderately flat & Media & \\
\hline & & & Composition & Criteria & Color assigned \\
\hline & \multirow[t]{2}{*}{ SOILS } & & $\begin{array}{l}\text { Fine materials } \\
\text { such as silt and } \\
\text { clays }\end{array}$ & Media & \\
\hline & & Measurement & Variable & Criteria & Color assigned \\
\hline & \multirow[t]{2}{*}{ PRECIPITATION } & $\begin{array}{c}500 \mathrm{~mm}^{-} \\
1000 \mathrm{~mm} / \mathrm{a}\end{array}$ & $\begin{array}{c}\text { Moderate } \\
\text { precipitation }\end{array}$ & Average & \\
\hline & & Range\% & Variable & Criteria & Color assigned \\
\hline & \multirow[t]{2}{*}{ PENDING } & \multirow[t]{3}{*}{$0 \%$} & Completely Flat & High & \multirow{3}{*}{ Color assigned } \\
\hline & & & Composition & Criteria & \\
\hline CLASSIFICATION 3 & SOILS & & $\begin{array}{l}\text { Floodplains, } \\
\text { flood zones) }\end{array}$ & High & \\
\hline
\end{tabular}

Escobar, A. A. H., Solorzano, D. R. V., \& Gamez, M. R. (2018). Susceptibility to flooding in abdon calderon of canton portoviejo parish. International Journal of Life Sciences, 2(3), 111-120. https://doi.org/10.29332/ijls.v2n3.220 


\begin{tabular}{|c|c|c|c|c|}
\hline & & $\begin{array}{l}\text { Vega of rivers, } \\
\text { flat areas, silt, } \\
\text { and clays. }\end{array}$ & & \\
\hline & Measurement & Variable & Criterion & Assigned color \\
\hline PRECIPITATION & $>800 \mathrm{~mm} / \mathrm{a}$ & $\begin{array}{c}\text { High } \\
\text { precipitation }\end{array}$ & High & \\
\hline
\end{tabular}

In table 3 , the weighting of the analysis criterion is shown.

Table 3

The weighting of the analysis criterion

\begin{tabular}{ccc}
\hline Variables & Degree of importance & $\begin{array}{c}\text { The criterion for the } \\
\text { analysis }\end{array}$ \\
\hline Pending & 3 & High \\
Geology & 2 & Average \\
Precipitation & 1 & Low \\
\hline
\end{tabular}

Table No. 3 shows that, for this investigation, the slope variable has the highest degree of importance and therefore constitutes the most important factor when evaluating susceptibility.

The variable soil is the second in importance of the present study and its transcendence lies in the composition of a particulate material whose composition determines land with a high probability of water saturation and being prone to flooding.

The precipitation variable occupies the third weighting in our analysis because its occurrence in our research field is uniform and does not vary in relation to the established criteria to assess susceptibility

\section{Results and Discussions}

\section{Description of the slope map}

(Berg et al., 2004), the Results section reports what was found in the study, and the Discussions section explains the meaning and significance of the results and provides suggestions for future directions of research. In this section, it is explained the results of research and at the same time is given the comprehensive discussion. Results can be presented in figures, graphs, tables, and others that make the reader understand easily. The discussion can be made in several sub-chapters.

According to the data obtained from the cartography (Portoviejo - Ecuador IV-3590 SERIE J721 of the area it was possible to obtain a slope map which results in the geomorphology of the relief that includes values between $0 \%$ and $<70 \%$, although in what corresponds to our field of research is between $0 \%$ and $5 \%$, which is an optimal condition for flooding regardless of the combination of other environmental factors. The presence of the low level of slopes is the result of the location in the lower part of the sub-basin of the Chico River and in its fluvial valley, which due to its natural condition are susceptible to flooding (IGM, 2014).

Other slope levels whose value comprises a variation of $5 \%$ to $70 \%$ but which are outside the study area and which were not taken into account to assess susceptibility, were also identified como se muestra en la figure 1. 


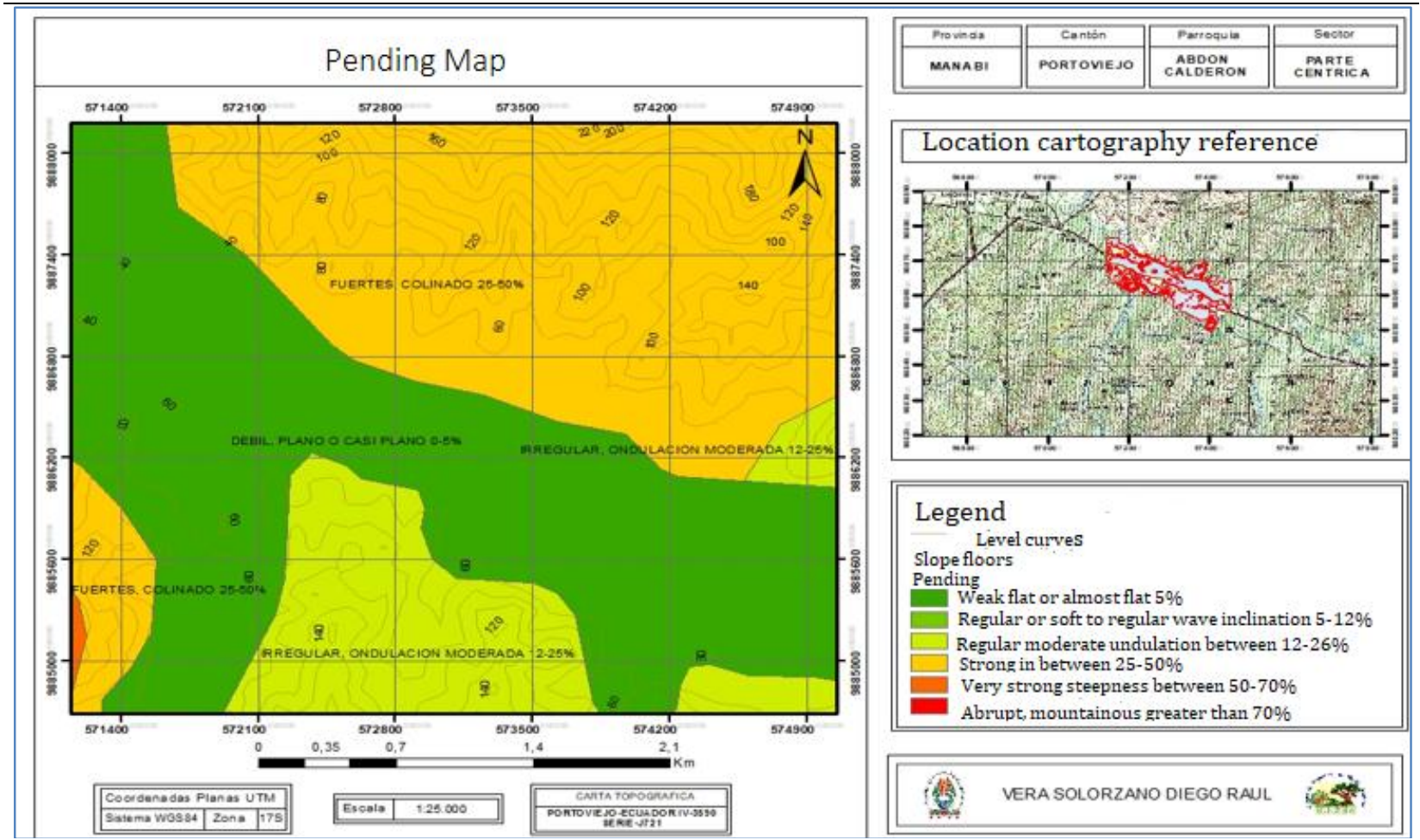

Figure 1. Slope levels whose value comprises a variation of $5 \%$ to $70 \%$

\section{Description of the soil map}

According to the international classification of soils (Soil Taxonomy USDA) (USDA, 2014) that groups them into large groups according to their characteristics, the soils of the parish belong to the group of Vertisols that are clay-rich soils that are generally found in humid zones of the river valleys as is the geoenvironmental context of our research.

Based on the results of the mapping used to prepare the map (Portoviejo - Ecuador IV-3590 SERIES J721), four levels can be distinguished according to the particle composition and all indicate that there is a high presence of clay and mineral material conglomerate that can be understood as larger particles and that groups sand, silt or gravel but in its laminar structure the clay is present.

Due to the results of the soil map in which we can observe formations of clay minerals in the rocks present in the study area, we determined that, although there are particles of conglomerates of larger size and that they may have a porosity, it is also estimated that the composition of the matrix of these contains clay so they constitute a waterproof material that once absorbed the water does not allow it to infiltrate and therefore make the surface susceptible to flooding.

In figure two the map with the categories of studied soils is shown. 


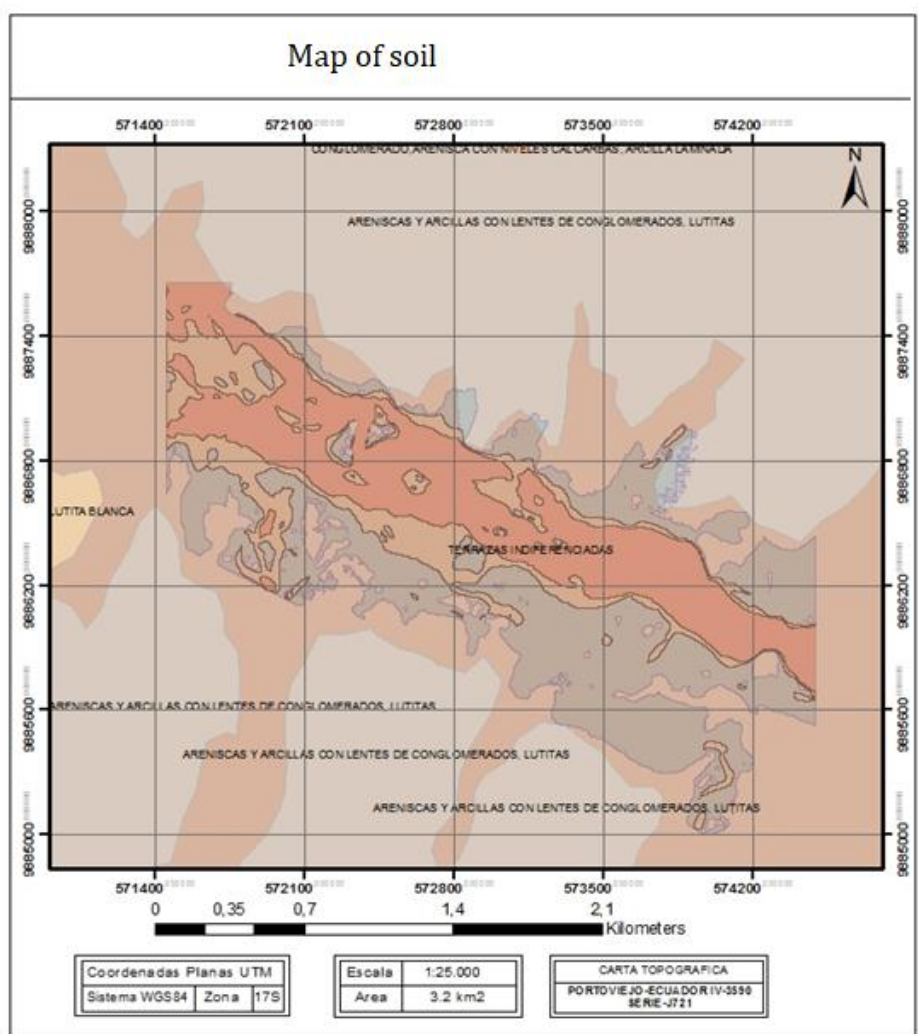

\begin{tabular}{|c||l|l|l|}
\hline Province & Canton & Parish & Sector \\
\hline MANABI & PORTOVIEJO & $\begin{array}{c}\text { ABDON } \\
\text { CALDERON }\end{array}$ & $\begin{array}{c}\text { PARTE } \\
\text { CENTRICA }\end{array}$ \\
\hline
\end{tabular}

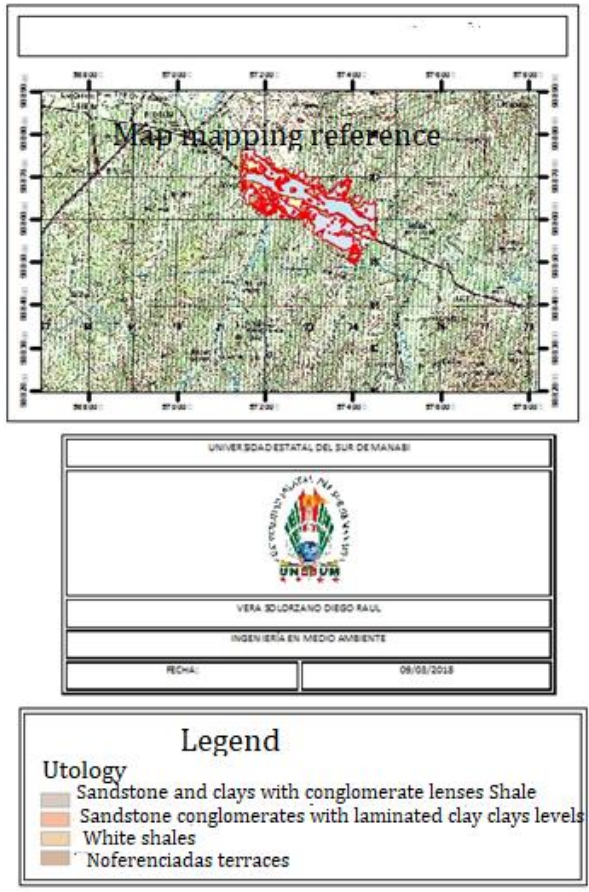

Figure 2. Soil types and their location

\section{Description of the susceptibility map}

Analyzing the map, one can see the areas with high, medium and low susceptibility. Likewise, if we analyze carefully its distribution in the place we can realize that the places of greater susceptibility are logically those more flat, with low or no slope located in the fluvial valley of the Rio Chico. The result of the susceptibility map reflects the exposure of the area to flooding in contrast to the historical review of previous phenomena that have already affected the area studied in different magnitudes.

The tour of the research area and the visualization of the environment also helped us establish a criterion that the areas closest to the river channel are more likely to be flooded by soil conditions and slopes with a low degree of slope. We could determine that by the appreciation of the place and the records of sequelae of floods that have already occurred before. The susceptible zones described in the map are the result of the direct incidence of the aforementioned factors that prove compliance with our research hypothesis.

The importance of the present investigation constitutes a precedent to determine that the risk is latent with a view towards the adequate management of the territory that implies recognizing those factors involved in it. Taking into account the information from other studies, it is confirmed that the susceptibility to floods is formed by the combination of many factors, especially three main ones; slope, soil and precipitation. All this context is configured specifically in the study area, a common situation that is repeated in many parts of the canton, the province and the country, in the figure 3 shows the flood susceptibility map. 

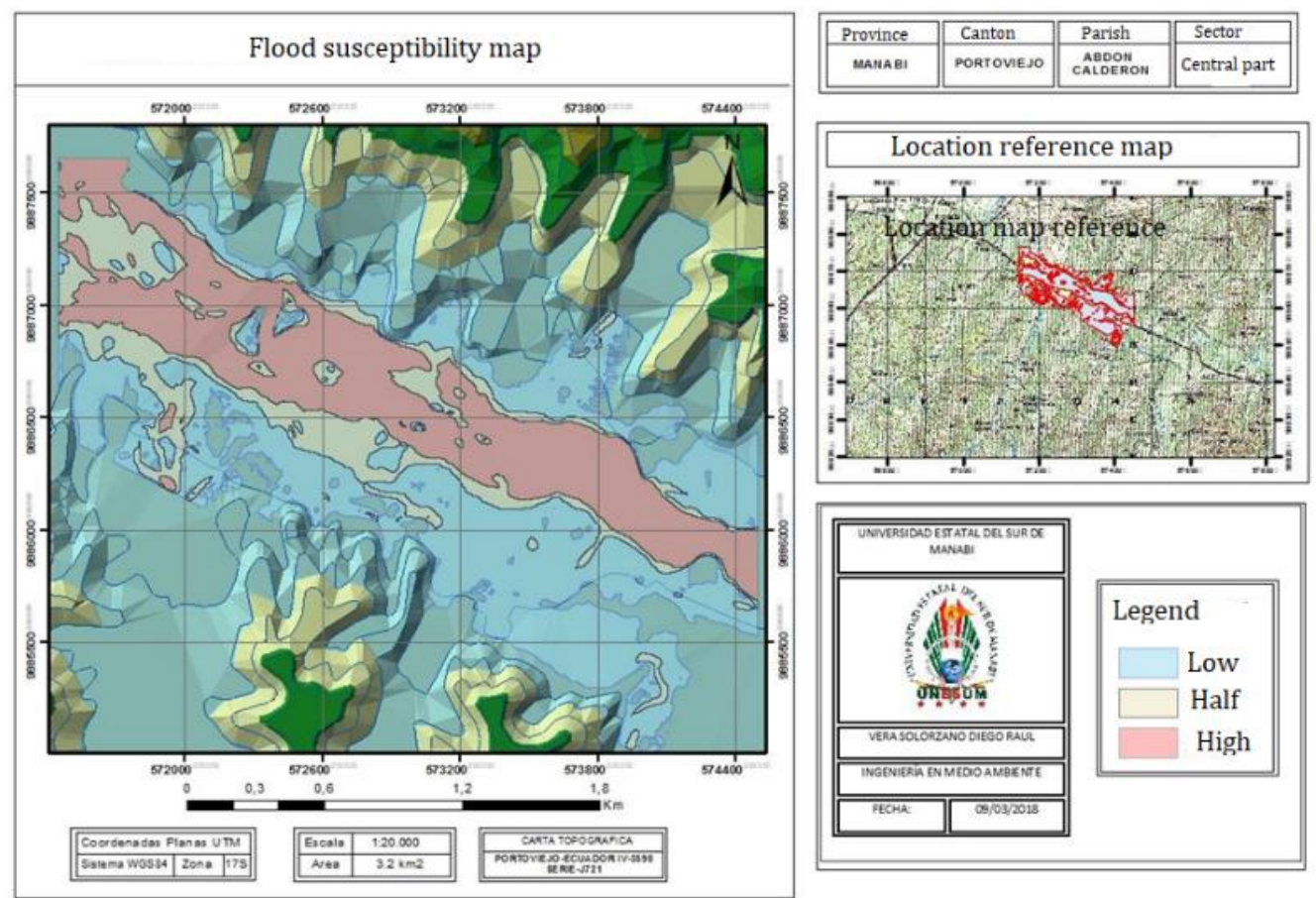

Figure 3. Susceptibility map for floods

As you can see the downtown area, it is one of the most vulnerable to flood susceptibility

For the development of the research work was taken into consideration the work done by (Moreno, 2016), where a study of similar characteristics was developed taking into account the biophysical conditions of the place and how they are related to the object of research (P \& 0., 2016).

Variables:

a) Slopes

b) Soils

c) Precipitations

In addition, a simple model of parameterization and weighting of the variables chosen for the study and the integral analysis of their respective thematic maps was chosen; a flood susceptibility map could be created due to the present geo-environmental characteristics and the valuation that we assign. As shown in table 4, the degree of importance and the analysis criteria obtained in the investigation have been evaluated.

Table 4

The degree of suitability obtained

\begin{tabular}{ccc}
\hline Variables & Degree of importance & Criterion for analysis \\
\hline Slopes & 3 & High \\
Soils & 2 & Medium \\
Precipitation & 1 & Low \\
\hline
\end{tabular}

Analyzing the susceptibility map you can see areas with high, medium and low susceptibility. Likewise, if we analyze carefully its distribution in the place we can realize that the places of greater susceptibility are logically those more flat, with low or no slope located in the fluvial valley of the Rio Chico.

Escobar, A. A. H., Solorzano, D. R. V., \& Gamez, M. R. (2018). Susceptibility to flooding in abdon calderon of canton portoviejo parish. International Journal of Life Sciences, 2(3), 111-120. 
The result of the susceptibility map reflects the exposure of the area to flooding in contrast to the historical review of previous phenomena that have already affected the area studied in different magnitudes.

\section{Conclusion}

The extensive literature review regarding the research topic allowed us to identify how flood susceptibility is configured in the parish center of the Abdón Calderón parish. The most influential determining factors and triggers of floods in the study area are low slopes, soil composition, and rainfall. The elaboration of thematic maps of the soil and slope variables allowed us to identify signs of flood susceptibility in our field of research. The obtaining of the flood susceptibility map identified the zones with high, medium and low susceptibility in the central part of the parish according to the analysis carried out. It was identified that the area most susceptible to flooding in the central part of Abdón Calderón corresponds to the entire terrace of the Río Chico fluvial valley, which is precisely the lowest area and comprises 114 hectares in the north-west direction of the project area.

Acknowledgments

The authors would like to thank the UTM for their support funding of the present article. 
References

Berg, B. L., Lune, H., \& Lune, H. (2004). Qualitative research methods for the social sciences (Vol. 5). Boston, MA: Pearson.

Espinosa, Salinas, M. A., \& Jiménez, M. (2014). Centro nacional de prevencion de desastres. Obtenido de

Herrero, A. D., Laín-Huerta, L., \& Isidro, M. L. (2008). Mapas de peligrosidad por avenidas e inundaciones: guía metodológica para su elaboración (No. 1). IGME.

IGM. (2014). Carta topografica de Portoviejo.

IPCC. (2017). Cambio climático 2007. Informe de síntesis. (2. Grupo Intergubernamental de Expertos sobre el Cambio Climático, Ed.) ISBN 92-9169-322-7.

Jha, A. K., Bloch, R., \& Lamond, J. (2012). Ciudades e inundaciones.

Meza, A. K. T., Freyre, J. R. A., Cevallos, M. G. O., \& Pico, M. J. M. (2018). Autonomy, Good Humor and Support Networks, Potential of Community Resilience Intervention in People Victims of the Earthquake in the Calderón Parish. International Research Journal of Management, IT and Social Sciences (IRJMIS), 5(1), 1-8.

Moreno, A., McPhail, S., \& Bove, R. (2016). 2007. International Status of Molten Carbonate Fuel Cell (MCFC) Technology, 196-208.

Organización Panamercana de la Salud, O. (2008). Informe de inundaciones en el Ecuador.

P, C. M., \& O., O. B. (2016). ANÁLISIS DEL RIESGO POR INUNDACIÓN UTILIZANDO HERRAMIENTAS.

S.N. (2010). Inundaciones. Madrid : Instituto de Estudios sobre Conflictos y Acción Humanitaria (IECAH).

Sarkar, D. (2004). Lattice graphics.

Secretaría de Gestión de Riesgos. (2014). Plan Estratégico Institucional 2014 - 2017.

USDA, F. (2014). Oilseeds: world markets and trade. Available at:(accessed 10 December 2014).

World Health Organization, \& Research for International Tobacco Control. (2008). WHO report on the global tobacco epidemic, 2008: the MPOWER package. World Health Organization.

Escobar, A. A. H., Solorzano, D. R. V., \& Gamez, M. R. (2018). Susceptibility to flooding in abdon calderon of canton portoviejo parish. International Journal of Life Sciences, 2(3), 111-120.

https://doi.org/10.29332/ijls.v2n3.220 


\section{Biography of Authors}

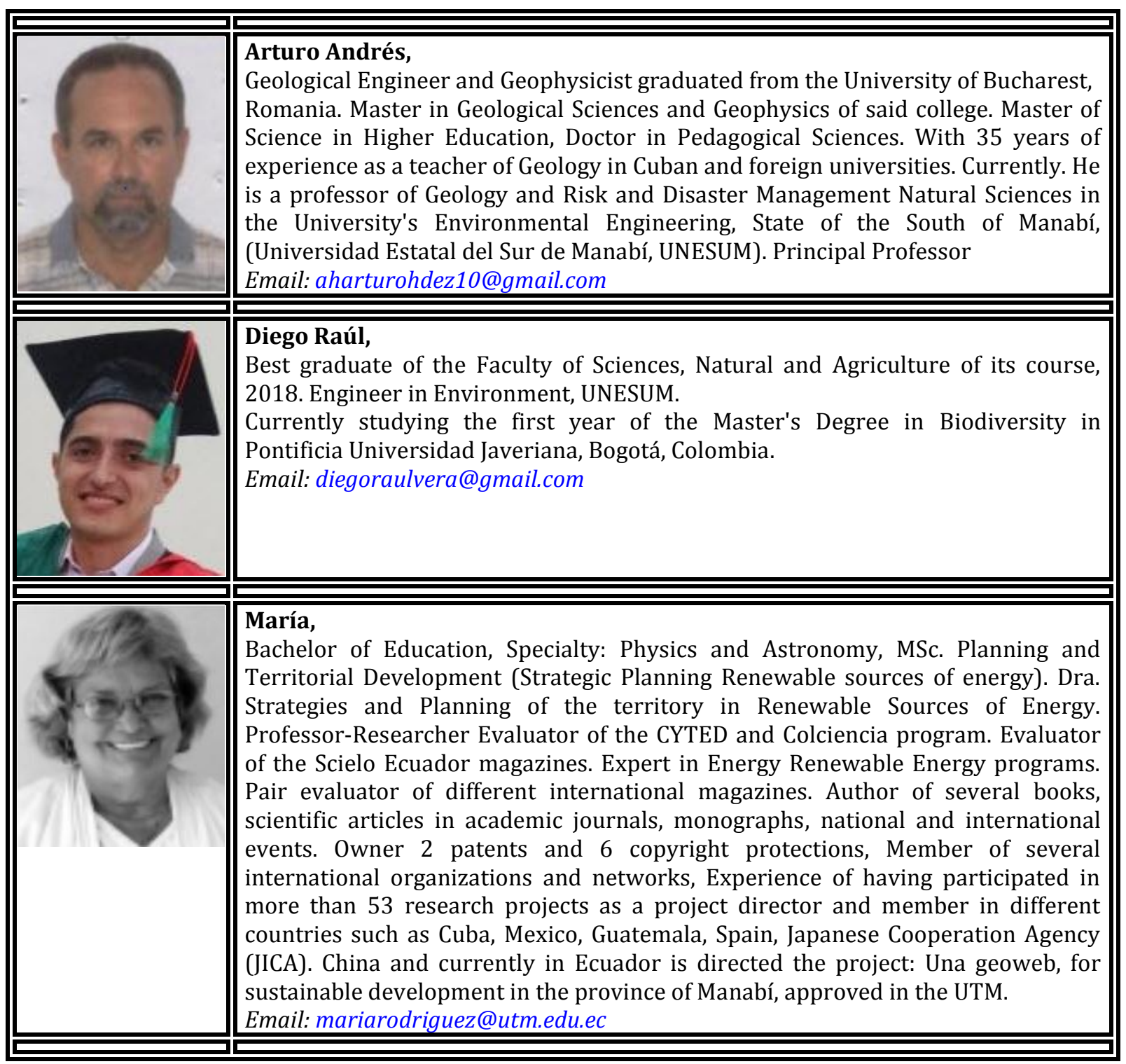

